\title{
The Adoption of the Treasury Single Account (Tsa) and Its Effect on Revenue Leakages of Nigerian States
}

\author{
Dr. Joseph. F. Adebisi, Ph.D., FCNA, ACTI, MNIM, MACFEI, CPA-Ireland \\ Okike B. Matthew, BSC. M. SC., CNA
}

Nigerian College of Accountancy, Kwall near Jos, Plateau State, Nigeria benthew2000@gmail.com

\begin{abstract}
The Treasury Single Account (TSA) is a system of accounting in the public sector where all government revenue generated are paid into a single central account. It is an efficient way of managing public fund for efficient and effective people oriented government. More so, it has been identified by the Federal Government of Nigeria as an efficient tool for curbing revenue leakage, which some state government have adopted and implemented, but it is not certain how this has played out so far at the state level. As such it is imperative to study the effectiveness of the TSA in Nigerian state. Primary data were collected from via question while the analysis was done using regression analysis with the aid of SPSS 22. The result of the study revealed that the TSA adoption is an effective tool for curbing revenue leakage in Nigerian states. It is recommended that those states that are yet to adopt the TSA, adopt and implement it for efficient fund management and curbing revenue leakage. In addition, that adequate working system of the TSA should be put in place to ensure its objective is achieved.
\end{abstract}

Keywords: Treasury Single Account, Revenue Generation, Revenue leakage, Fund management

\section{INTRODUCTION}

The Treasury Single Account (TSA) is a system of accounting in the public sector where all government revenue generated are paid into a single account at the Central Bank. TSA is believed to be an efficient and effective means of managing government revenue generation and system that provide and enforce sufficient self-control mechanism on revenue generation and budget implementation using a daily return from account balances of various Ministries, Departments and Agencies (MDAs) into a central account. The primary aim of TSA implementation is to ensure optimum public fund management and maximize the use of cash resources through concentration and reduction in float costs. To further substantiate this, the International Monetary Fund (IMF) working paper (2010) states that treasury single account (TSA) is an essential tool for consolidating and managing governments' cash resources, thus minimizing borrowing costs.

The TSA solutions are designed to capture detailed information about the government's cash resources and spending on a daily basis. The TSA is a modern cash management system that enhance government ability to safeguard public funds and suitable for good governance, transparency and accountability of every Naira generated or expended.

Eme, Chukwurah and Emmanuel (2015) states that " the payment of government revenue into multiple bank accounts operated by MDAs in commercial banks, as obtained under the old order, was clearly against the 
Nigerian Constitution which, in Sections 80 and 162, directed that all federally-collected revenues should be paid into the Federation Account". They further state that it was a flagrant breach of the constitution that underscores the rot in the management of the country's finances. It was on this ground that President Muhammadu Buhari on $9^{\text {th }}$ August, 2015 invoked Section 80 (1) of the 1999 constitution as amended which state that "All revenues, or other moneys raised or received by the Federation (not being revenues or other moneys payable under this Constitution or any Act of the National Assemble into any other public fund of the Federation established for a specific purpose) shall be paid into and form one Consolidative Revenue Fund of the Federation" by directing that all government Ministries, Departments and Agencies (MDAs) should close all their accounts domiciled in the commercial banks and transfer the balance to the federation account that is the TSA. This is part of his effort to sanitize the country and fight against financial leakages and corruption. Though, President Goodluck Jonathan had given the same directive in January with February $28^{\text {th }}, 2015$ as the deadline, the directive was ignored by the agencies. The noncompliance is blamed on his lack of political will to ensure compliance. The TSA is seen as a solution to stalling leakages in revenue generation and making more funds available to the government which in turn increase government efficiency. The TSA has been identified by the Federal Government of Nigeria as an efficient tool for curbing revenue leakage, although it is not certain how this has played in Nigeria so far.

It is in view of this advantages and prospects of TSA that some state government have also adopted and implement the TSA in their states. It is against this backdrop that the study aims to look at how this adoption has played out so far at the state level. Has the adoption curb leakages and fund diversion in these state and has is increase the revenue based of the state, thereby making more funds available to the state governments to execute projects. As such it is imperative to evaluate the effectiveness of the TSA in Nigerian states.

\section{MEANing OF TSA}

The TSA is synonymous to a family operating a joint account where the salary of the father who is a civil servant, the mother's income who is a business woman and children's income from their various sources (business and salary) are paid into the family joint account; from which all their expenditure is charged. The same applies to TSA where the family is the government, the father, mother and the children are the government ministries, Departments and Agencies (MDAs) while the family joint account is the TSA. The IMF working paper (2010) defined TSA as, "a unified structure of government bank account that gives a consolidated view of government cash resources". Based on the principle of unity of cash and unity of treasury, TSA is a bank account or a set of linked accounts through which the government transacts all its receipts and payments. The CBN (2015) states that "Centralized banking is system whereby banking arrangements of entities are integrated within a single account or set of linked accounts. This model could be referred to as Treasury Single Account (TSA) for the purpose of enhancing cash management" p.3. In Nigeria the TSA is the existing Consolidated Revenue Fund (CRF) which is maintained at CBN for the purpose of all receipts and payments. Some may argue that the TSA makes it difficult to distinguish individual incomes of the various revenue generation head/MDAs, but the principle of unit follows from the fungibility of all cash irrespective of its end use. While it is necessary to distinguish individual cash transactions for control and reporting purposes, this purpose is achieved through

the accounting system and not by holding/depositing cash transaction to specific bank account. This enables the treasury to delink management of cash from control at transaction level. 


\section{The BASic Principles of An EFfective TSA SySTEM}

An effective and efficient TSA system as provided by the IMF (2010) should depict three basic principles which include

- Unified Account: The government banking arrangement should be unified, to enable ministries of finance/ treasury oversight function of government cash flows in and out of this bank account and allow complete fungibility of all cash resource. Including a real time-basis of electronic banking in place. Although a TSA structure can contain larger sub-accounts in a single banking institution (not necessary a Central Bank) it can accommodate external zero balance accounts (ZBAs) in a number of commercial banks. These separate accounts should be integrated with a top account (called the TSA main account) usually at the central bank for netting off their balances (usually at the end of each day) to get the consolidated cash position.

- Complete Control: No other government agency should operate bank accounts outside the oversight of the treasury. Institutional structures and transaction processing arrangements determine how a TSA is accessed and operated. The treasury/ministry of Finance, as the chief financial agent of the government, should manage the government's cash (and debt) positions to ensure that sufficient funds are available to meet government financial obligations, idle cash is efficiently invested, and debt is optimally issued according to the appropriate statures. In some cases, debt management including issuance of debt being done by a Debt Management Office (DMO). They treasury/Ministry of finance should have complete control of all government revenue regardless of the account location.

- Complete Coverage: The TSA should have comprehensive coverage. It should ideally include cash balances of all government entities, both budgetary and extra-budgetary, to ensure full consolidation of government's cash resources. No government MDA whether fully or party funded should be excluded from the TSA.

\section{Zero Balance Account (ZBA)}

The zero balance account system also known as the imprest account is an accounts opened by the government MDAs maintained at the commercial banks with zero Naira balance from where payments are made or received. The balances from such accounts are transferred to the TSA at the end of each day. This accounts with the commercial banks are maintained to enable the MDAs transact with individuals and corporate entities because they do not have accounts with the CBN. The zero account balance systems is designed to enable the CBN at the end of each day provide the government with its account balance or financial standing as well as reduce idle fund and to enable the government meet up with its immediate cash needs.

\section{TSA BANK ACCOUNTS STRUCTURE}

Under the TSA system the bank accounts can be centralized or decentralized.

- Centralized Bank Account. In this situation there is a central payment system for all government income expenditure. The centralized accounting structure for payment of all government expenditure through the central treasury who may operate with or without regional offices. Such that the central treasury has the exclusive authority/access to the TSA and payment of expenditure of budget heads. All the expenditure/ budget institutions submit their payment requests to the central treasury before making payment. Such a transaction processing structure could be associated with either the centralized payment system or the distributed payment system. Where either the centralized authority/treasury operates the TSA main account and transaction accounts or there could be separate transaction accounts for each regional treasury unit. 
- Decentralized Bank Accounts. Under this structure in addition to the centralized TSA account there are several banks accounts operated as ZBA opened by the MDAs with commercial banks for their transactions. The balances on such accounts are transferred to the TSA at the end of each day. The balance can either be debit or credit balance. Where there is a negative balance transferred to the TSA from any of the accounts with the commercial banks at the end of the day. At the start of the following day payments are made to clear the negative along with the imprest due to such Ministry, Department of Agency as long as the payments are approved from the consolidate cash with the central bank, which manages the TSA. The accounts at the commercial banks are linked to the TSA for control and to propel speedy transaction between the accounts. In each of the structure it imperative that at the end of each day the balance on the accounts are transferred to the TSA. This way the government is able to efficiently manage its funds.

\section{BENEFITS OF TSA}

According to Pattanyak the TSA has the following benefits to the Government:

i. Ensures complete, real-time information on government cash resource. The government at any time can ascertain what it has on its coffers. The TSA being electronically powered provides the government with actual and comprehensive account standing at any point in time they required such information.

ii. Helps preparation of accurate and reliable cash flow forecasts. With TSA in place governments account are reliably maintain with high level of accuracy and on timely basis. The availability of accurate and reliable cash flow statements of the government makes it easy for the government and the revenue office to prepare a substantive cash flow projection upon which the governments rely to make short and long term plans.

iii. Optimizes the cost of government operations. The TSA will ensure that there are no idle funds. Before the introduction of the TSA the cost of governance was high because there some government expenditure heads that had to borrow to meet their immediate financial needs where as there are some other MDAs that keep their surplus or funds which are not immediately needed in an account with the commercial banks. This same money is borrowed to those government MDAs with immediate financial needs attracting interest there by increasing the cost of governance.

iv. Facilitates efficient payment mechanism. It is necessary to minimize the interval between the time when cash is received and the time it is available for carrying out expenditure programs. The e-payments system that is employed to ensure efficient TSA operation will facilitate prompt payments. There will be no avenue for corrupt government official to keep salaries and other forms of payment in fixed deposits for their selfish interest. Since the e-payment platform will provide detail of all payments and to whom it is made. Thus, payments will be promptly made to the right beneficiaries.

v. Improved operational and appropriation control during budget execution. The adoption of Treasury Singe Account will lead to improved control on budget appropriation and execution by the government. TSA will help the government monitor and ensure efficient budget implementation. Hence, there will be proper accountability for every money spent by the government MDAs on the execution of budgets which will translate to expedient budget implementation.

vi. Enhances efficiency and timeliness of bank reconciliation. The bank reconciliation statements will be timely since the payments are electronically designed. The government at any point in time know what went out of or came into it coffer and the balance in connection it its cash book. 
vii. Facilitates timely and more complete accounting statement/reports. The preparation of financial report will be more comprehensive and timely. The required information for the preparation of accounts and financial report will be readily available whenever it is needed since all transactions are electronically maintained.

\section{EXCEPTIONS TO TSA}

All government fully or partially funded MDAs are expected to comply with the TSA instruction by the President to closes all accounts with commercial banks and transfers the balances to the TSA. However, there are exceptions to the instruction as pointed by Taiwo (2015) Organizations where government is only a shareholder and public corporations that are providing commercial rather than social services should be excluded to avoid hampering their operations given the level of bureaucracy in government. Examples include organizations such as Asset Management Corporation of Nigeria (AMCON), Federal Mortgage Bank, and the Sovereign Wealth Fund p.9. These entities though exempted from the TSA, are required to maintain an account with the CBN where all its revenue will be paid and are allowed to only withdraw from the account maximum of the amount approved in their budget.

\section{Role of Commercial BANKS In ENSURING EFFECTIVE TSA}

a. The commercial banks are to serve government revenue collection units. The commercial banks are expected to aid in collecting revenues to the government which are expected to be transferred to the TSA at the CBN at the end of each day. Hence the banks has an important role to play in ensuring that funds due to the government are collected and transferred to the TSA.

b. Provide online linkage with Government Integrated Financial Management System (GIFMIS) to facilitate payment instructions and receipt of funds.

c. Remit collections into accounts with CBN, for agencies funded by the budget remit to CRF while for those partially/not funded by the budget, transfer to their individual designated accounts. Adhere to agreement guiding the operations of TSA payment gateway

d. The banks provide avenue for separation and recognition of revenue generated by each government Ministry, Department and Agencies for the purpose of accountability and reporting. The bank provide solution to the challenge of inability to separate the revenue generated by various government MDAs.

e. They ensure optimum performance of payment Gateway by being available at all to users to effect transactions between government and individuals or corporate entities.

\section{TSA IMPLEMENTATION CHALLENGES}

The primary concerned is the Section 22(1) which permits all Ministries, Departments and Agencies (MDAs) that generate revenue to remit $80 \%$ percent of their operating surplus to the Consolidated Revenue Fund Account. This allowed these MDAs to defraud the government of funds that should have been remitted to its coffers by fraudulently inflation of their operating costs very high. By so doing in most cases they declared and remit to the government very low operating surplus (Okwe, Chijioke, Temiloluwa and Ogah, 2015:52).

The major challenge of the TSA implementation is corruption. The Nigerian political system has been characterized as corrupt and lacking the will and power to prosecute culpable parties. This is already playing as the National assembly which is supposed to oversee the compliance is lobbying for exception from the 
TSA. In an attempt to keep the public in dark on the expensive cost of governance which the TSA is aiming to end. Another major challenge is the inadequate knowledge and sensitization of the people on the benefit of TSA. There have be inadequate sensitization of those in position of implementing the TSA and masses on the importance and benefit of TSA to the economic development of the nation and efficient resource allocation and budget implementation.

\section{Methodology}

Research methodology serves as a guide to collect, analyse and interpret research observations. In pursuance of achieving the research objective and proffering solution to the research problem the study employed survey research. The target population is the 628 Senior and Management staffs of the Ministries of Finance and Board of Internal Revenue of 6 selected states in Nigeria that have adopted the TSA. In selecting the sample size for this study, the Okpanachi (2011) restructured Yemane (1967) sampling model is employed to justify the sufficiency of the sample size. The formula applied is given as

$\mathrm{n}=\mathrm{N} /\left(3+\mathrm{N} \mathrm{e}^{2}\right)$

Where $\mathrm{n}=$ Number of samples, $\mathrm{N}=$ Total population, $\mathrm{e}=$ Error tolerance and $3=$ adjusted constant.

$$
\mathrm{n}=828 /\left(3+628 \times 0.05^{2}\right)=137
$$

The data used for analysis are collected through the use of likert scale closed ended structured questionnaire. Questionnaires were distributed to the sample size of 133 staffs out of which 124 were fully completed and returned.

The analysis is done using the regression analysis:

$$
\mathrm{Y}_{\mathrm{i}}=\beta_{0}+\beta_{1} \mathrm{X}_{\mathrm{i} 1}+\beta_{2} \mathrm{X}_{\mathrm{i} 2}+\ldots+\beta \mathrm{pX} \mathrm{X}_{\mathrm{ip}}+\varepsilon_{\mathrm{i}}
$$

Where: $Y_{i}=$ dependent variable the subscript indexes a particular observation

$\beta_{0}=$ regression intercept

$\beta_{1}$ to $\beta_{\mathrm{p}}=$ slope of the various independent variables

$\mathrm{X}_{\mathrm{ij}}$ is $=$ the $\mathrm{i}^{\text {th }}$ observation of the $\mathrm{j}^{\text {th }}$ independent variable and where the first independent variable takes the value 1 for all $i$.

$\varepsilon_{\mathrm{i}}=$ error term and the subscript íindexes a particular observation.

$i=1 \ldots, n$

Source: Francis and Michael (2012)

$\operatorname{RevL}_{\mathrm{it}}=\beta_{\mathrm{o}}+\beta_{1}$ FundTSAct $_{\mathrm{t}}+\beta_{2} \operatorname{RevG}_{\mathrm{t}}+\mathrm{e}_{\mathrm{t}}$

RevL: Revenue Leakage

FundTSAct= Fund Available due to Treasury Single Account

RevG: Revenue Generation

HYPOTHESIS

Ho: Treasury Single Account adoption has no significant effect on Revenue leakage of Nigerian States 


\section{ANALYSIS}

Variables Entered/Removed ${ }^{a}$

\begin{tabular}{|l|c|c|l|}
\hline Model & Variables Entered & Variables Removed & \multicolumn{1}{c|}{ Method } \\
\hline 1 & RevGen, AvailFund ${ }^{\mathrm{b}}$ & & Enter \\
\hline
\end{tabular}

a. Dependent Variable: RevLeakage

b. All requested variables entered

\section{Model Summary}

\begin{tabular}{|l|r|r|r|r|}
\hline Model & R & R Square & \multicolumn{1}{|c|}{ Adjusted R Square } & Std. Error of the Estimate \\
\hline 1 & $.428^{\mathrm{a}}$ & .183 & .170 & .61932 \\
\hline
\end{tabular}

a. Predictors: (Constant), RevGen, AvailFund

ANOVA $^{\mathrm{a}}$

\begin{tabular}{|c|c|c|c|c|c|c|}
\hline \multicolumn{2}{|c|}{ Model } & Sum of Squares & df & Mean Square & F & Sig. \\
\hline \multirow{3}{*}{1} & Regression & 10.429 & 2 & 5.215 & 13.595 & $.000^{\mathrm{b}}$ \\
\cline { 2 - 7 } & Residual & 46.410 & 121 & .384 & & \\
\cline { 2 - 7 } & Total & 56.839 & 123 & & & \\
\end{tabular}

a. Dependent Variable: RevLeakage

b. Predictors: (Constant), RevGen, AvailFund

Coefficients $^{\mathrm{a}}$

\begin{tabular}{|c|l|r|r|r|r|r|}
\hline \multicolumn{2}{|l|}{ Model } & \multicolumn{2}{|c|}{ Unstandardized Coefficients } & \multicolumn{2}{c|}{$\begin{array}{c}\text { Standardized } \\
\text { Coefficients }\end{array}$} & \multirow{2}{*}{ Sig. } \\
\cline { 3 - 7 } \multicolumn{2}{|c|}{} & B & Std. Error & Beta & & \\
\hline \multirow{2}{*}{1} & (Constant) & 3.167 & .362 & & 8.755 & .000 \\
\cline { 2 - 7 } & AvailFund & .523 & .101 & .495 & 5.175 & .000 \\
\cline { 2 - 7 } & RevGen & -.521 & .163 & -.307 & -3.206 & .002 \\
\hline
\end{tabular}

a. Dependent Variable: RevLeakage

In the model summary table, $\mathrm{R}$ Square value indicates that $18.3 \%$ of the variance in Leakage can be predicted from the independent variables TSA and Revenue Generation. From the coefficient table we found that the p-values of .000 and .002 are less than 0.05 . This indicate the TSA adoption has significant effect on Revenue Leakage. Therefore, the null hypothesis that Treasury Single Account adoption has no significant effect on Revenue leakage of Nigerian States is rejected.

\section{CONCLUSION AND RECOMMENDATION}

The findings of the analysis revealed that TSA adoption is effective in curbing revenue leakage. This is an indication that the TSA is a reliable means of public fund management that will govern the management, allocation and application of government funds to people oriented projects that will result in economic development and improve living standards of Nigerians. It will also serve as a means of reducing government overhead cost, idle funds and make more funds available to meet immediate needs of the government. Therefore, it is recommended that those states that are yet to adopt the TSA, adopt and implement the TSA for efficient fund management and curbing revenue leakage. In addition, that adequate working system of the TSA be put in place to ensure its objective is achieved.

Volume 2 


\section{REFERENCES}

Eme, O. I., Chukwurah D. C and Emmanuel N.I. (2015). An analysis of Pros and Cons Treasury Single Account Policy in Nigeria, Arabian Journal of Business and Management Review, Vol . 5, No.4

CBN (2015). Centralized Banking and E-collection Retrieved from, hhtp://oagf.gov.ng/wp-content/ uploads/2015/05/FGN-eCllection-Presentation-by-CBN.pdf

International Treasury fund (IMF) 2010. Treasury Single Account: Concept, Design, and Implementation Issues, IMF Working Paper WP/10/143

Okpanachi J. (2011): Impact of Merger and Acquisition on Financial Performance of Banks in Nigeria. A PhD. Dissertation Submitted to the Department of Economics and Management Sciences, NDA Kaduna

Okwe M., Chijioke N., Temiloluwa A. and Ogah D. (2015). Treasury Single Account: Giving Life to Jonathan's 'dead' Policy Directives', Sunday Guardian

Taiwo O. (2015). Treasury Single Account and Taxation (part 1), BUSINESS DAY, Wednesday, 07 October 2015

Pattanayak S. (2010). Establishing a Treasury Single Account (TSA)-Concept Issues and Challenges, The International Consortium on Government Financial Management (ICFGM) maintains this public financial management blog.

\section{APPENDIX}

\section{RESEARCH QUESTIONNAIRE}

Dear Respondent,

[Senior Staff members of State Ministries of Finance only]

We are staffs of the Nigerian College of Accountancy Kwall Plateau State conducting research titled:

"The adoption of the Treasury Single Account (TSA) and its Effect on Revenue Leakages of Nigerian States"

Basically the research seeks to explore the empirical relationship between the TSA adoption with leakage in revenue generation and revenue generation of State Governments in Nigeria. You have been selected to participate in this noble academic research. While your co-operation in completing the questionnaire is valued, participation is voluntary. The results will be used only in an aggregated form and therefore, your anonymity and the confidentiality of responses are assured as no information gained from this survey will be identified with any particular person or ministry.

Thank you in anticipation of your co-operation.

Please tick $[\mathrm{X}]$ in the most appropriate option from the list of options that followed the questions below.

PART - General Information

\begin{tabular}{|l|l|l|l|l|l|l|l|l|l|l|}
\hline A1 & Location & $\begin{array}{l}\text { North- Central } \\
{[1]}\end{array}$ & $\begin{array}{l}\text { North-East } \\
{[2]}\end{array}$ & $\begin{array}{l}\text { North-West } \\
{[3]}\end{array}$ & $\begin{array}{l}\text { South-South } \\
{[4]}\end{array}$ & $\begin{array}{l}\text { South- East } \\
{[5]}\end{array}$ & $\begin{array}{l}\text { South- West } \\
{[6]}\end{array}$ \\
\hline
\end{tabular}




\begin{tabular}{|l|l|l|l|l|l|l|l|l|}
\hline A2 & $\begin{array}{l}\text { Department } \\
\text { within your } \\
\text { Institution }\end{array}$ & $\begin{array}{l}\text { Main Account } \\
\text { Department } \\
{[1]}\end{array}$ & $\begin{array}{l}\text { Revenue } \\
\text { Department } \\
{[2]}\end{array}$ & $\begin{array}{l}\text { Expenditure Control } \\
\text { Department } \\
{[3]}\end{array}$ & $\begin{array}{l}\text { Other } \\
\text { Departments } \\
{[4]}\end{array}$ \\
\hline
\end{tabular}

\begin{tabular}{|l|l|l|l|l|l|}
\hline A3 & Staff (Respondent) Status & \multicolumn{2}{|l|}{$\begin{array}{l}\text { Management Staff } \\
{[1]}\end{array}$} & & $\begin{array}{l}\text { Senior Staff } \\
{[2]}\end{array}$ \\
\hline A4 & $\begin{array}{l}\text { Select the option that best describe your position } \\
\text { in the ministry/department }\end{array}$ & $\begin{array}{l}\text { Decision Making } \\
\text { Staff [1] }\end{array}$ & $\begin{array}{l}\text { Project Execution Staff } \\
\text { [2] }\end{array}$ \\
\hline
\end{tabular}

Please tick $[\mathrm{X}]$ in the most appropriate option from the list of options that followed the question below

PART B - Revenue Generation

\begin{tabular}{|c|c|c|c|c|c|c|}
\hline \multicolumn{2}{|c|}{ Revenue Generation in the State } & \multirow{2}{*}{$\begin{array}{c}\text { Very Low } \\
\text { [1] }\end{array}$} & \multirow{2}{*}{$\begin{array}{l}\text { Low } \\
{[2]}\end{array}$} & \multirow{2}{*}{$\begin{array}{c}\text { Moderate } \\
\text { [3] }\end{array}$} & \multirow{2}{*}{$\begin{array}{l}\text { High } \\
{[4]}\end{array}$} & \multirow{2}{*}{$\begin{array}{c}\text { Very High } \\
{[5]}\end{array}$} \\
\hline \multicolumn{2}{|r|}{$\begin{array}{l}\text { Select the option that best describes your State } \\
\text { level Revenue Generation since Adopting TSA :- }\end{array}$} & & & & & \\
\hline B1 & General Revenue Generation in the State & {$[$ ] } & [ ] & [ ] & [ ] & [ ] \\
\hline B2 & $\begin{array}{l}\text { Revenue Generated by Ministries and } \\
\text { Department }\end{array}$ & [ ] & [ ] & [ ] & [ ] & [ ] \\
\hline B3 & Revenue Generated from Tax & [ ] & [ ] & [ ] & [ ] & [ ] \\
\hline B4 & $\begin{array}{l}\text { Revenue Generated by State Owned Tertiary } \\
\text { Institutions }\end{array}$ & [ ] & [ ] & [ ] & [ ] & [ ] \\
\hline B5 & $\begin{array}{l}\text { Revenue Generated by the state board of internal } \\
\text { revenue }\end{array}$ & [ ] & [ ] & [ ] & [ ] & [ ] \\
\hline B6 & Revenue Generated from other Sources & [ ] & [ ] & [ ] & [ ] & [ ] \\
\hline
\end{tabular}

Please tick $[\mathrm{X}]$ in the most appropriate option from the list of options that followed the question below

\section{PART C - Leakage of Revenue Generation}

\begin{tabular}{|c|c|c|c|c|c|c|}
\hline \multicolumn{2}{|c|}{ Leakage in Revenue } & \multirow{2}{*}{$\begin{array}{c}\text { Very Low } \\
\text { [1] }\end{array}$} & \multirow{2}{*}{$\begin{array}{c}\text { Low } \\
\text { [2] }\end{array}$} & \multirow{2}{*}{$\begin{array}{c}\text { Moderate } \\
\text { [3] }\end{array}$} & \multirow{2}{*}{$\begin{array}{l}\text { High } \\
\text { [4] }\end{array}$} & \multirow{2}{*}{$\begin{array}{c}\text { Very High } \\
{[5]}\end{array}$} \\
\hline $\begin{array}{l}\text { Indi } \\
\text { sinc }\end{array}$ & $\begin{array}{l}\text { cate the level of leakage in the state revenue } \\
\text { e adopting TSA :- }\end{array}$ & & & & & \\
\hline $\mathrm{C} 1$ & Leakage during revenue collection & [ ] & [ ] & [ ] & [ ] & [ ] \\
\hline $\mathrm{C} 2$ & Leakage in revenue remittance & [ ] & [ ] & [ ] & [ ] & [ ] \\
\hline $\mathrm{C} 3$ & Leakage caused by revenue collection system & [ ] & [ ] & [ ] & [ ] & [ ] \\
\hline $\mathrm{C} 4$ & Diversion of revenue collection for the state & [ ] & [ ] & [ ] & [ ] & [ ] \\
\hline $\mathrm{C} 5$ & $\begin{array}{l}\text { Inadequate remittance of revenue collected for } \\
\text { the state }\end{array}$ & [ ] & [ ] & [ ] & [ ] & [ ] \\
\hline C6 & $\begin{array}{l}\text { Revenue payment to scammers who pose as } \\
\text { revenue collection officers }\end{array}$ & [ ] & [ ] & [ ] & [ ] & [ ] \\
\hline
\end{tabular}

Volume 2 
Please tick $[\mathrm{X}]$ in the most appropriate option from the list of options that followed the question below PART D - Treasury Single Account (TSA)

\begin{tabular}{|c|c|c|c|c|c|c|}
\hline \multirow{2}{*}{\multicolumn{2}{|c|}{$\begin{array}{l}\text { Treasury Single Account (TSA) Effect on Available } \\
\text { Funds } \\
\text { Choose the option that best describes the effect of } \\
\text { Treasury Single Account (TSA) adoption in your State :- }\end{array}$}} & \multirow{3}{*}{$\begin{array}{c}\text { Very Low } \\
\text { [1] } \\
{[]}\end{array}$} & \multirow{3}{*}{$\begin{array}{r}\text { Low } \\
{[2]} \\
{[]}\end{array}$} & \multirow{3}{*}{$\begin{array}{c}\text { Moderate } \\
{[3]} \\
{[]}\end{array}$} & \multirow{3}{*}{$\begin{array}{c}\text { High } \\
\text { [4] } \\
{[]}\end{array}$} & \multirow{3}{*}{$\begin{array}{c}\begin{array}{c}\text { Very High } \\
\text { [5] }\end{array} \\
{[\text { ] }}\end{array}$} \\
\hline & & & & & & \\
\hline D1 & Availability of fund for project execution & & & & & \\
\hline D2 & Rate of Resource allocation & [ ] & [ ] & [ ] & [ ] & [ ] \\
\hline D3 & Rate of Idle state government fund & [ ] & [ ] & [ ] & [ ] & [ ] \\
\hline $\mathrm{D} 4$ & Prompt payments to contractors & [ ] & [ ] & [ ] & [ ] & [ ] \\
\hline D5 & $\begin{array}{l}\text { Ability of the state government to ascertain the } \\
\text { amount available to it at all time }\end{array}$ & [ ] & [ ] & [ ] & [ ] & [ ] \\
\hline D6 & Efficiency of fund/cash management & [ ] & [ ] & [ ] & [ ] & [ ] \\
\hline
\end{tabular}

Thank you for the cooperation

Dr. Joseph. F. Adebisi, Ph.D, FCNA, ACTI, MNIM, MACFEI and Okike. B. Matthew, Bsc. M. Sc., CNA

Citation: Dr. Joseph. F. Adebisi, Ph.D., FCNA, ACTI, MNIM, MACFEI, Okike B. Matthew, BSC. M. SC., CNA. "The Adoption of the Treasury Single Account (Tsa) and Its Effect on Revenue Leakages of Nigerian States", American Research Jornal of Business and Management Volume 2; pp:1-10

Copyright (C) 2016 Dr. Joseph. F. Adebisi, Ph.D., FCNA, ACTI, MNIM, MACFEI, Okike B. Matthew, BSC. M. SC., CNA. This is an open access article distributed under the Creative Commons Attribution License, which permits unrestricted use, distribution, and reproduction in any medium, provided the original work is properly cited. 